\title{
Integrated maize protection in Poland - current state of research and implementation
}

\author{
Integrowana ochrona kukurydzy w Polsce \\ - aktualny stan badań i wdrożeń
}

\author{
Paweł K. Bereś ${ }^{1}$, Marek Mrówczyński², Marek Korbas² ${ }^{2}$ Adam Paradowski $^{2}$
}

\begin{abstract}
Summary
The integrated plant protection will be obligatory in the European Union from 1 January 2014. With respect to maize (Zea mays L.) protection the new approach to reduce the number and harmfulness of pest populations does not bring radical changes in the control methods used so far, however it offers their more rational utilization. Taking into consideration the integrated plant protection against the pests all non-chemical methods are preferred for the pest control, and if their application is not effective, the use of chemical pesticides is recommended in order to maintain pest populations below the levels not causing economic losses. Particular emphasis should be put on the monitoring of the pests to analyse the needs and optimal dates for their effective control.

This paper presents the current advances in research on maize protection carried out at the Institute of Plant Protection - National Research Institute (IPP - NRI) in the last few years. Field and laboratory experiments carried out within the framework of scientific and research programme of IPP - NRI may contribute to development and updating the methodology for integrated maize protection against weeds, pests and diseases.
\end{abstract}

Key words: Zea mays L., Poland, integrated plant protection, weeds, pests, diseases

\section{Streszczenie}

Integrowana ochrona roślin będzie obligatoryjnie stosowana w Unii Europejskiej od 1 stycznia 2014 roku. W odniesieniu do kukurydzy (Zea mays L.) nowy sposób podejścia do ograniczania liczebności i szkodliwości agrofagów nie wprowadza rewolucyjnych zmian w metodach jakie dotychczas stosowano, jednak pozwala bardziej zracjonalizować ich wykorzystanie. Integrowana ochrona roślin za priorytetowe uznaje wykorzystanie wszystkich niechemicznych metod ograniczania zagrożenia ze strony agrofagów, a dopiero w ostateczności zezwala na użycie chemicznych środków ochrony roślin, w oparciu o progi ekonomicznej szkodliwości, jeśli takie zostały wyznaczone w tej metodzie. Szczególny nacisk kładzie się na monitorowanie występowania agrofagów oraz ustalenie potrzeb i terminów ich optymalnego zwalczania.

W pracy przedstawiono aktualny postęp w pracach badawczych prowadzonych nad kukurydzą realizowanych w Instytucie Ochrony Roślin - Państwowym Instytucie Badawczym (IOR - PIB) w ostatnich kilku latach. Doświadczenia polowe oraz laboratoryjne wykonywane w ramach tematyki naukowo-badawczej IOR - PIB wykorzystywane są do tworzenia oraz aktualizowania metodyki integrowanej ochrony kukurydzy przed chwastami, szkodnikami i chorobami.

Słowa kluczowe: Zea mays L., Polska, integrowana ochrona roślin, chwasty, szkodniki, choroby

\footnotetext{
1 Instytut Ochrony Roślin - Państwowy Instytut Badawczy

Terenowa Stacja Doświadczalna

Langiewicza 28, 35-101 Rzeszów

pawel.beres@iorpib.poznan.pl

${ }^{2}$ Instytut Ochrony Roślin - Państwowy Instytut Badawczy

Władysława Węgorka 20, 60-318 Poznań
} 


\section{Wstęp / Introduction}

W Polsce uprawa kukurydzy (Zea mays L.) cieszy się dużą popularnością wśród rolników, co odzwierciedla systematycznie rosnący areał uprawy tej rośliny. Jak podaje Michalski (2009) o ile jeszcze w latach 1996-2000 powierzchnia zasiewów tej rośliny na ziarno i kiszonkę wynosiła 251 tys. ha, tak w 2010 roku wzrosła do 675,6 tys. ha (Sulewska 2011). Z kolei w 2011 roku areał uprawy kukurydzy przekroczył 700 tys. ha (Michalski 2012), natomiast w 2012 roku osiagną̧ rekordowy poziom ponad miliona hektarów, w tym aż 544 tys. ha zajmowała kukurydza ziarnowa (Michalski 2013).

Wraz z rosnącą powierzchnią uprawy, intensyfikacją produkcji, stosowaniem uproszczeń agrotechnicznych oraz występowaniem korzystnych warunków agrometeorologicznych dla licznego rozwoju organizmów szkodliwych wzrasta zagrożenie dla tej rośliny ze strony agrofagów (Bereś i Pruszyński 2008). Ich liczne wystąpienie może prowadzić do bezpośrednich strat w plonach surowca do zakiszania oraz ziarna dochodzących lokalnie do 30-40\%, a w sprzyjających rozwojowi warunkach nawet do 50 i więcej procent. Ponadto wystapienie organizmów szkodliwych znacznie pogarsza jakość produktu finalnego oraz surowca do dalszego przerobu (Bereś i wsp. 2007a). Dodatkowe straty w plonach mogą powstawać wskutek skażenia plonu mikotoksynami produkowanymi przez niektóre gatunki grzybów, a których dopuszczalny poziom zawartości regulują odpowiednie normy prawne (Korbas i Horoszkiewicz-Janka 2007).

Wobec dużej szkodliwości agrofagów dla roślin kukurydzy konieczne stało się ograniczanie ich liczebności oraz szkodliwości z wykorzystaniem zalecanych metod. Począwszy od stycznia 2014 roku w całej Unii Europejskiej będzie do tego celu stosowana integrowana ochrona roślin, której obowiązek stosowania na państwa członkowskie nałożyła Dyrektywa Parlamentu Europejskiego i Rady Unii Europejskiej nr 2009/128/WE z dnia 21 października 2009 roku ustanawiająca ramy wspólnotowego działania na rzecz zrównoważonego stosowania pestycydów.

Integrowana ochrona roślin zgodnie $\mathrm{z}$ definicją przyjętą przez Międzynarodową Organizację Biologicznego i Integrowanego Zwalczania Szkodliwych Roślin i Zwierząt (International Organisation for Biological and Integrated Control of Noxious Animals and Pests - IOBC) rozumiana jest jako zwalczanie agrofagów przy użyciu wszystkich dostępnych metod zgodnie $\mathrm{z}$ wymaganiami ekonomicznymi, ekologicznymi i toksykologicznymi, które dają pierwszeństwo naturalnym czynnikom ograniczającym i uwzględniają ekonomiczne progi zagrożenia (Olszak i wsp. 2000).

Strategia integrowanej ochrony roślin opiera się na trzech zasadniczych elementach, którymi są:

- zapobieganie występowaniu i namnażaniu się agrofagów,

- prowadzenie obserwacji upraw i podejmowanie odpowiednich decyzji,

- interwencji, gdy metody bezpośredniego zwalczania są konieczne dla uratowania wysokości i jakości plonów (Pruszyński i wsp. 2012).
Integrowana ochrona roślin będzie obligatoryjnie stosowana przez wszystkich użytkowników ochrony roślin od 2014 roku, niemniej podstawowe zasady integracji zostały wdrożone już do praktyki rolniczej w ramach certyfikowanego systemu Integrowanej Produkcji (IP) niektórych upraw warzywniczych, sadowniczych i rolniczych. System taki już w Polsce funkcjonuje i regulowany jest przepisami ustawy o ochronie roślin z dnia 18 grudnia 2003 roku (Dz. U. z 2008 r. Nr 133, poz. 849) oraz rozporządzeniem Ministra Rolnictwa i Rozwoju Wsi z dnia 16 grudnia 2010 roku w sprawie integrowanej produkcji (Dz. U. z 2010 r. Nr 256, poz. 1722). Jak podaje definicja opracowana przez Międzynarodową Organizację Biologicznego Zwalczania - „Integrowana produkcja jest systemem prowadzenia gospodarstw, zabezpieczającym produkcję wysokiej jakości środków żywności i innych produktów, wykorzystując zasoby naturalne i mechanizmy regulujące w miejsce środków stanowiących zagrożenie oraz w celu zabezpieczenia zrównoważonego rozwoju" (Boller i wsp. 2004).

$\mathrm{W}$ ramach integrowanej produkcji, która zgodnie z Art. 5 ustawy o ochronie roślin nadzorowana jest przez Państwową Inspekcję Ochrony Roślin i Nasiennictwa (PIORiN), tworzone są metodyki IP, które określają zasady prowadzenia upraw w tym systemie.

Jedną z nielicznych roślin rolniczych, która posiada opracowana przez Instytut Ochrony Roślin - Państwowy Instytut Badawczy (IOR - PIB) metodykę integrowanej produkcji jest kukurydza (Zea mays L.). Zasady opisane w tym opracowaniu zostały w 2009 roku wdrożone do praktyki rolniczej przez Głównego Inspektora Ochrony Roślin i Nasiennictwa (Metodyka 2009). W metodyce IP kukurydzy poświęcono wiele uwagi zagadnieniom integrowanego ograniczania liczebności i szkodliwości najważniejszych agrofagów tej rośliny. $Z$ uwagi jednak na postęp naukowy, zmiany w doborze odmian, środków ochrony roślin i uwarunkowań prawnych, a także rozszerzanie się składu gatunkowego agrofagów metodyka ta jest systematycznie aktualizowana.

Celem opracowania jest zaprezentowanie badań z ostatnich kilku lat dotyczących integrowanej ochrony kukurydzy przed agrofagami, jakie są prowadzone w IOR - PIB i systematycznie wdrażane do praktyki rolniczej w formie zaleceń.

\section{Integrowana ochrona kukurydzy przed chwastami - aktualny stan badań i wdrożeń Integrated maize protection against weeds - current state of research and implementation}

Wycofanie kilka lat temu z rejestru substancji czynnej atrazyny stało się bodźcem do poszukiwania nowych rozwiązań dotyczących odchwaszczania kukurydzy (Paradowski 2008; Paradowski i Kierzek 2009). Wprowadzenie na rynek taniego i skutecznego środka lub metody odchwaszczania o zbliżonym do atrazyny działaniu i cenie nie należy do łatwych zadań. Konieczne jest jednak kontynuowanie badań nad bezpiecznymi dla kukurydzy i środowiska preparatami chemicznymi oraz systemem ochrony tej rośliny przed zachwaszczeniem. 
Takie działanie jest ściśle związane z zaleceniami integrowanej ochrony.

Zastąpienie atrazyny jednym środkiem w świetle wyników światowych badań jest aktualnie niemożliwe. W tym zakresie zdecydowanie dominują badania nad stosowaniem mieszanin herbicydowych z wykorzystaniem obniżonych dawek. W IOR - PIB prowadzone są doświadczenia w dwóch kierunkach. Jedne dotyczą stosowania w dwóch terminach tego samego herbicydu lub mieszaniny herbicydowej. Drugi kierunek to stosowanie również w dwóch terminach mieszanin, przy założeniu, że każdy $\mathrm{z}$ zabiegów zawiera różne substancje czynne. Ten kierunek dodatkowo zabezpiecza plantacje przed zjawiskiem kompensacji oraz zjawiskiem uodparniania się chwastów.

W celu dostosowania zabiegów do zmiennych warunków klimatycznych testowane są różne terminy aplikacji herbicydów. Najczęściej rozpatrywano warianty obejmujące zabieg doglebowy i nalistny lub dwa nalistne. Z kolei zabiegi nalistne wykonywane były również w różnych fazach rozwojowych kukurydzy. Najlepsze efekty uzyskiwano stosując zabiegi na jak najmłodsze chwasty (do fazy 4 liści właściwych). Dużą rolę w stosowaniu dawek obniżonych i dzielonych spełniają kombinacje herbicydowe $\mathrm{z}$ łącznym stosowaniem adiuwantów.

Badania nad efektywnością odchwaszczania kukurydzy w zależności od terminu i metody aplikacji herbicydów zostały przeprowadzone między innymi przez Kierzka i wsp. (2011), którzy przebadali kilka herbicydów aplikując je w dawkach obniżonych od 30 do $75 \%$ w stosunku do podstawowych dawek zalecanych (zarejestrowanych) i stosowanych w różnych terminach. Herbicydy stosowano w trzech wariantach:

- dwukrotnie na chwasty $w$ fazie nie przekraczającej 2 liści właściwych, bez względu na fazę rozwojową kukurydzy,

- zabieg doglebowy + zabieg nalistny,

- dwa zabiegi nalistne - w fazie 1-3 oraz 4-6 liści kukurydzy.

W badaniach wykorzystano następujące substancje czynne: acetochlor, dikamba, linuron, florasulam + 2,4-D, fluroksypyr, foramsulfuron + jodosulfuron, nikosulfuron, nikosulfuron + rimsulfuron i rimsulfuron. Badania wykazały, że po zastosowaniu obniżonych dawek herbicydów istnieje możliwość uzyskania zadowalającego efektu chwastobójczego. Najlepszym komponentem w badanych mieszaninach herbicydów okazała się kombinacja florasulam + 2,4-D.

$\mathrm{Z}$ uwagi na to, że kukurydza należy do upraw o szerokich międzyrzędziach, stąd też można na plantacjach zastosować klasyczne metody integrowane, czyli mechaniczne zwalczanie chwastów, uzupełnione o ochronę chemiczną. Jedną $\mathrm{z}$ metod ograniczenia zużycia herbicydów są ponadto zabiegi pasowe w międzyrzędziach (Bereś i wsp. 2007a).

Ważnym zagadnieniem prowadzonym w ramach doświadczeń nad integrowanym programem ograniczania zachwaszczenia na polach kukurydzy jest monitoring ich składu gatunkowego $\mathrm{z}$ uwzględnieniem gatunków chwastów dotąd w tej uprawie nie spotykanych lub spotykanych sporadycznie na poziomie nie zagrażającym plantacji. Jednym z takich gatunków jest bodziszek drobny i iglica pospolita, które zaczęły pojawiać się w kukurydzy, w ilościach przekraczających ponad 100 roślin $/ \mathrm{m}^{2}$. Dość często spotykane są plantacje, na których występuje kompensacja, np. bardzo rzadko w kukurydzy występującego chabra bławatka lub, co jest częściej spotykane, rdestu powojowego (rdestówki powojowatej). Typowym problemem do rozwiązania jest pojawienie się na południu kraju nowego, ciepłolubnego gatunku o intensywnym wzroście, którym jest zaślaz pospolity (Abutilon theophrasti). Przeciętnie jego wysokość wynosi około $150 \mathrm{~cm}$, ale egzemplarze o wysokości $250 \mathrm{~cm}$ nie należą do rzadkości. Ochrona przed tym gatunkiem jest konieczna, ponadto należy podjąć intensywne badania $\mathrm{z}$ uwagi na bardzo skromne informacje o jego wrażliwości na herbicydy.

\section{Integrowana ochrona kukurydzy przed szkodnikami - aktualny stan badań i wdrożeń Integrated maize protection against pests - current state of research and implementation}

Obok roślinności niepożądanej coraz poważniejsze zagrożenie na plantacjach kukurydzy w Polsce zaczynają stanowić szkodniki, wśród których dominuja przedstawiciele gromady owadów (Insecta) (Bereś i Pruszyński 2008). Podwaliny pod obecnie prowadzone doświadczenia nad tą grupą agrofagów dały badania Kani (1962a, b) wykonywane w południowo-zachodniej Polsce, a w późniejszym czasie prace Lisowicza (1996), które wykonano w południowo-wschodniej części kraju.

$\mathrm{W}$ ramach aktualnie realizowanych w IOR - PIB prac badawczych prowadzi się monitoring ich występowania oraz szkodliwości, a także ocenę składu gatunkowego. Jak podają Bereś i Pruszyński (2008) liczba szkodników stwierdzanych w zasiewach kukurydzy wynosi aktualnie ponad 20 gatunków, przy czym systematycznie pojawiają się nowe zagrożenia. Jednym $\mathrm{z}$ nich jest organizm kwarantannowy - stonka kukurydziana (Diabrotica virgifera LeConte), która pojawiła się po raz pierwszy w Polsce, w 2005 roku, w województwie podkarpackim (Sahajdak i wsp. 2006), a do końca 2011 roku wystapiła w 9 województwach (PIORiN 2011). Systematycznie pojawiają się także gatunki, dla których kukurydza staje się alternatywnym źródłem pożywienia, bądź miejscem rozwoju. Przykładem są skrzypionki (Oulema spp.), wieczernica szczawiówka (Acronicta rumicis L.), włócznica białożyłka (Simyra albovenosa Goeze), piętnówka brukwianka (Lacanobia oleracea L.), urazek kukurydziany (Glischrochilus quadrisignatus Say) czy też przędziorek chmielowiec (Tetranychus urticae Koch) (Boroń i Mrówczyński 2005; Mrówczyński i wsp. 2007; Bereś 2011a).

$\mathrm{W}$ badaniach wykonanych w ostatnich latach, w południowo-wschodniej Polsce obok identyfikacji nowych gatunków owadów występujących na plantacjach kukurydzy (Bereś 2011a) skupiono się także nad dokładnym rozpoznaniem składu gatunkowego szkodników występującego już od wielu lat. Przykładem są badania Kucharczyk i wsp. (2011) dotyczące składu gatunkowego wciornastków (Thysanoptera) żerujących na kukurydzy oraz badania Beresia (2011b) nad rolnicami (Agrotinae). 
Większość prowadzonych prac badawczych skupia się na gatunkach ważnych $\mathrm{z}$ gospodarczego punktu widzenia. Zalicza się do nich: omacnicę prosowiankę (Ostrinia nubilalis Hbn.), ploniarkę zbożówkę (Oscinella frit L.), rolnice, a także mszyce (Aphididae), wciornastki oraz stonkę kukurydzianą jako gatunek podlegający obowiązkowemu zwalczaniu. $\mathrm{Na}$ bieżąco monitoruje się występowanie tych owadów między innymi dla potrzeb określenia konieczności ich chemicznego zwalczania oraz wyznaczenia optymalnego terminu zabiegu. W ostatnich latach badania $\mathrm{z}$ tego zakresu wykonano $\mathrm{w}$ odniesieniu do omacnicy prosowianki (Bereś 2012a), mszyc (Bereś 2011c), wciornastków (Kucharczyk i wsp. 2011) oraz stonki kukurydzianej (Bereś i wsp. 2009; Drzewiecki i Pietryga 2009; Bereś i Sionek 2010). Monitorowanie obecności i liczebności gatunków szkodliwych dla potrzeb krótko- lub długookresowego prognozowania występowania agrofagów oraz ustalania terminów ich optymalnego zwalczania należy do najważniejszych czynności podejmowanych w integrowanej ochronie roślin (Matyjaszczyk i wsp. 2010).

Niewielka część badań związana była także z oceną szkodliwości gryzoni pojawiających się na plantacjach kukurydzy (Skorupska 2005), a także oceny skuteczności wybranych repelentów w odstraszaniu dzików (Węgorek i Giebel 2008).

$\mathrm{Z}$ uwagi na to, że $\mathrm{w}$ integrowanych programach ochrony roślin duży nacisk położono na stosowanie metod niechemicznych do ograniczania liczebności i szkodliwości agrofagów, stąd też prowadzi się doświadczenia między innymi nad wpływem monokultury oraz zmianowania na niektóre gatunki szkodliwe. Badania Beresia (2007) dotyczące porównania tych dwóch systemów uprawy na szkodliwość $O$. nubilalis wskazuja, że uproszczenia agrotechniczne (w tym przypadku monokultura) mogą zwiększać liczebność tego gatunku, a zwłaszcza ryzyko pojawienia się uszkodzeń roślin decydujących o wysokości i jakości plonu, tj. uszkodzonych kolb czy też łodyg złamanych poniżej kolby. Wskazano także, że kilkuletnia monokultura zwiększa liczebność chrząszczy stonki kukurydzianej nawet 7-9-krotnie w porównaniu do systemu, gdzie stosuje się zmianowanie roślin (Bereś i Kaniuczak 2010).

W integrowanych programach ochrony niezmiernie ważne jest również dobieranie do uprawy takich odmian kukurydzy, które $\mathrm{z}$ jednej strony są dostosowane do uprawy w lokalnych warunkach glebowo-klimatycznych (rejony uprawy kukurydzy), a z drugiej strony są mniej podatne na uszkodzenia powodowane przez niektóre gatunki. Większość wykonanych prac dotyczy oceny podatności odmian na zasiedlenie przez ploniarkę zbożówkę, omacnicę prosowiankę oraz stonkę kukurydzianą. Badano także wpływ wczesności wybranych mieszańców kukurydzy na liczebność bądź szkodliwość owadów szkodliwych, co pozwala plantatorom częściowo wpływać na wielkość i charakter szkód przez nie powodowanych. Badania $\mathrm{z}$ tego zakresu w IOR - PIB prowadzone są od kilkunastu już lat, niemniej $\mathrm{z}$ uwagi na systematyczne zmiany w doborze odmian, a zwłaszcza rejestrację nowych i wycofywanie starszych mieszańców są corocznie ponawiane. W ostatnim czasie tego typu doświadczenia przeprowadzono między innymi dla omacnicy prosowianki (Bereś 2010a; Bereś i Górski 2012), stonki kukurydzianej (Bereś i Kaniuczak 2010) oraz przędziorka chmielowca (Skorupska 2011). Badania $\mathrm{z}$ tego zakresu realizowane są również przez specjalistów z Uniwersytetu Przyrodniczego w Poznaniu i dodatkowo poszerzane o wpływ innych czynników (np. nawożenia, terminu siewu, gęstości siewu, itp.) na najważniejsze gatunki szkodliwe (Sulewska i Ptaszyńska 2007; Sulewska i wsp. 2011; Szymańska i wsp. 2011). Stałą ocenę podatności odmian kukurydzy na niektóre agrofagi prowadzi się również w Centralnym Ośrodku Badania Odmian Roślin Uprawnych (COBORU), a także w ramach Porejestrowego Doświadczalnictwa Odmianowego (PDO). W przypadku niektórych gatunków polifagicznych, jak np. omacnicy prosowianki, monitoruje się jej liczebność i szkodliwość dla wybranych roślin żywicielskich - kukurydzy pastewnej, kukurydzy cukrowej i sorgo (Bereś 2012b).

Obok doboru odmian mniej podatnych, jedną z metod stosowanych w integrowanych programach ochrony kukurydzy przed szkodnikami jest uprawa kukurydzy transgenicznej. W Europie możliwa jest uprawa jedynie kukurydzy linii MON 810 kodującej wytwarzanie białka Cry1Ab toksycznego dla szkodników z rzędu Lepidoptera, a w szczególności $O$. nubilalis oraz Sesamia nonagrioides Lef., które stanowią duże zagrożenie dla plonów tej rośliny na kontynencie europejskim. W IOR - PIB wykonano również doświadczenia nad przydatnością tego typu odmian w ograniczaniu szkodliwości omacnicy prosowianki, które potwierdziły ich wysoką odporność na żerowanie szkodnika (Bereś 2010b). Dodatkowo w ramach projektu badawczego nr PBZ-MNiSW-06/01/2007 koordynowanego przez Instytut Hodowli i Aklimatyzacji Roślin - Państwowy Instytut Badawczy, przy współudziale Szkoły Głównej Gospodarstwa Wiejskiego w Warszawie, Uniwersytetu Przyrodniczego we Wrocławiu oraz IOR PIB Terenowej Stacji Doświadczalnej w Rzeszowie wykonano doświadczenia nad wpływem kukurydzy MON 810 na organizmy niedocelowe, co $\mathrm{z}$ kolei ma duże znaczenie dla ochrony bioróżnorodności odgrywającej kluczową rolę $w$ metodach integrowanych. Tematyką przydatności kukurydzy modyfikowanej genetycznie dla polskiego rolnictwa i jej wpływem na omacnicę prosowiankę zajmowano się także na Uniwersytecie Przyrodniczym w Poznaniu (Sobiech i wsp. 2011), Uniwersytecie Przyrodniczym w Lublinie (Haliniarz i Bojarczyk 2007) oraz na Uniwersytecie Przyrodniczym we Wrocławiu (Twardowski i wsp. 2008).

$\mathrm{Z}$ racji tego, że integrowana ochrona roślin promuje stosowanie metod proekologicznych, w tym biologicznych, stąd też w IOR - PIB podjęto badania nad wrogami naturalnymi wybranych gatunków szkodników kukurydzy. $\mathrm{W}$ praktyce rolniczej zastosowanie ma jedynie kruszynek (Trichogramma spp.) stosowany do ograniczania szkodliwości omacnicy prosowianki. Dotychczas oceniono skuteczność jajobójczą dla $O$. nubilalis kilku gatunków kruszynka, tj. Trichogramma evanescens, T. pintoi oraz T. embryophagum stosowanych w ramach jednej lub dwóch introdukcji (Lisowicz i Kot 1999; Bereś i Lisowicz 2005; Bereś 2008). Aktualnie w IOR - PIB prowadzi się także badania nad skutecznością $T$. brassicae oraz nad 
łącznym zastosowaniem Trichogramma spp. z Bacillus thuringiensis do ograniczania szkodliwości omacnicy prosowianki. Doświadczenia nad przydatnością czynników biologicznych w ograniczaniu szkodliwości $O$. nubilalis $\mathrm{w}$ ostatnim czasie prowadzone były również i w innych krajowych ośrodkach naukowych, gdzie badano między innymi skuteczność zwalczania tego gatunku na kukurydzy cukrowej z wykorzystaniem grzyba Isaria fumosorosea (Kuźniar i wsp. 2012).

Integrowana ochrona roślin nie wyklucza również stosowania preparatów chemicznych, niemniej muszą być one wykorzystywane jedynie w ostateczności, gdy inne metody niechemiczne okażą się niewystarczające dla zabezpieczenia wysokości i jakości plonów (Bereś i wsp. 2007a). Zarejestrowane insektycydy muszą być wykorzystywane w sposób racjonalny, w oparciu o progi ekonomicznej szkodliwości (jeżeli zostały wyznaczone), w optymalnych terminach zwalczania i warunkach pogodowych gwarantujących ich wysoką skuteczność (Bereś i Pruszyński 2008).

Wykaz insektycydów dopuszczonych do stosowania w Polsce do ochrony kukurydzy przed szkodnikami sukcesywnie się zmienia. Jest to związane z pojawianiem się nowych preparatów na rynku, wycofywaniem z użycia dotychczas stosowanych lub procesem ich rerejestracji. Dodatkowo od niedawna możliwy jest już import równoległy środków ochrony roślin w obrębie Unii Europejskiej, co wymaga systematycznej aktualizacji zaleceń ochrony roślin.

Szczególnie dużą rolę w chemicznej ochronie kukurydzy przed szkodnikami odgrywa zastosowanie zapraw nasiennych, które są przeznaczone do ograniczania liczebności gatunków wczesnowiosennych, zwłaszcza odglebowych. Użycie zapraw insektycydowych traktowane jest jako zabieg proekologiczny, głównie z uwagi na to, że preparat chemiczny jest dokładnie odmierzony i zlokalizowany na ściśle określonej powierzchni, tj. okrywie owocowo-nasiennej ziarniaka, przez co spektrum jego oddziaływania na organizmy niedocelowe jest mniejsze aniżeli w przypadku zabiegów nalistnych wykonywanych nieselektywnymi preparatamii. W ramach badań prowadzonych w ostatnich latach w IOR - PIB oceniano między innymi wpływ zapraw insektycydowych na liczebność wciornastków (Bereś 2010c), a także ploniarki zbożówki oraz drutowców (Elateridae) (Drzewiecki i Pietryga 2008; Bereś 2011d). Zbliżone badania wykonywane były $w$ ostatnich latach także na Uniwersytecie Przyrodniczym w Poznaniu (Sulewska i wsp. 2009).

Obok zapraw nasiennych w zaleceniach ochrony kukurydzy przed szkodnikami znajdują się preparaty aplikowane nalistnie, stosowane głównie do zwalczania gatunków występujących w pełni okresu wegetacyjnego. W badaniach wykonanych w ostatnich latach w IOR - PIB dla potrzeb opracowania metodyki integrowanej produkcji kukurydzy testowano skuteczność kilku insektycydów nalistnych do zwalczania ploniarki zbożówki, omacnicy prosowianki oraz stonki kukurydzianej (Bereś 2006; Drzewiecki i Pietryga 2007; Bereś 2010d; Bereś i Drzewiecki 2011).

Z ochroną chemiczną ściśle wiąże się dbałość o pożyteczną entomofaunę zasiedlającą plantacje kukurydzy, a także o owady neutralne dla tej rośliny, rozwijające się na pozostawionych chwastach czy też poszukujące pokarmu oraz schronienia (Bereś i Pruszyński 2008). Pomimo, że wrogowie naturalni nie są w stanie, w sposób ciąłły ograniczać liczebności szkodników do poziomu poniżej progów ekonomicznej szkodliwości, to jednak producenci kukurydzy w ramach integrowanej ochrony muszą podejmować takie decyzje, które w możliwie jak największym stopniu pozwolą wykorzystać potencjał pożytecznej działalności pasożytów i drapieżców (Bereś i wsp. 2007b).

\section{Integrowana ochrona kukurydzy przed chorobami - aktualny stan badań i wdrożeń Integrated maize protection against diseases - current state of research and implementation}

Jeszcze do niedawna choroby kukurydzy były mało docenianą grupą agrofagów pojawiających się na plantacjach kukurydzy w Polsce. Na wzrost znaczenia gospodarczego sprawców chorób wpłynęła jednak ich rosnąca szkodliwość przejawiająca się spadkiem wysokości oraz jakości plonu, a w szczególności możliwością jego skażenia mikotoksynami wytwarzanymi między innymi przez grzyby rodzaju Fusarium. To głównie poznanie znaczenia gospodarczego mikotoksyn było czynnikiem odpowiedzialnym za wzrost zainteresowania praktyki rolniczej oraz środowiska naukowego chorobami występującymi na tej roślinie uprawnej. Zainteresowanie to wynika $\mathrm{z}$ potencjalnie bardzo dużej szkodliwości mikotoksyn na zdrowie, a nawet życie ludzi oraz zwierząt gospodarskich, stąd też odpowiednimi przepisami prawnymi zaczęto regulować dopuszczalną ich zawartość w plonach (Korbas i Horoszkiewicz-Janka 2007).

W sytuacji licznego wystapienia sprawców chorób i szkodników może dojść nawet do 50\% strat w plonach ziarna kukurydzy, a niekiedy nawet likwidacji zasiewu (Lisowicz i Tekiela 2004), stąd też dużego znaczenia w integrowanej ochronie tej rośliny nabierają działania profilaktyczne pozwalające ograniczyć ich liczny pojaw. Działania te są one szczególnie ważne w momencie, kiedy obserwuje się postępujące zmiany klimatyczne, a zwłaszcza ocieplanie się klimatu, które wpływa także na pojaw sprawców chorób, a także stosowanie w wielu gospodarstwach uproszczeń w agrotechnice (Korbas 2008; Korbas i wsp. 2008).

Kukurydza może być porażana lub zasiedlana przez blisko 400 gatunków patogenów należących do królestw: Mycota, Chromista i Protozoa. Najważniejsze rodzaje i gatunki powodujące choroby kukurydzy to: Phytophthora spp., Pythium debaryanum, P. ultimum, Sclerospora graminicola, Cochliobolus carbonum, Cochliobolus sativus, Gibberella zeae, Puccinia sorghi, Ustilago zeae, Alternaria alternata, A. brassicae, Botrytis cinerea, Cercospora zeae-maydis, Cladosporium herbarum, Fusarium acuminatum, $F$. avenaceum, $F$. culmorum, $F$. graminearum, F. moniliforme, $F$. oxysporum, F. solani, Colletotrichum graminicola, Diplodia zeae, Rhizoctonia solani (Korbas 2006). Jak podaje cytowany autor do 
najczęściej występujących chorób kukurydzy w Polsce należą: głownia guzowata kukurydzy, drobna plamistość liści kukurydzy, zgorzel siewek i zamieranie kiełków, zgnilizna korzeni i zgorzel podstawy łodygi, fuzarioza kolb kukurydzy, głownia pyląca, rdza kukurydzy oraz helminosporioza kukurydzy.

W ostatnich latach, w IOR - PIB badania z zakresu chorób kukurydzy koncentrowały się w dużej mierze na monitorowaniu występowania oraz szkodliwości poszczególnych patogenów. Doświadczenia z tego zakresu prowadzone były między innymi w odniesieniu do głowni guzowatej kukurydzy (Korbas 2006; Tekiela 2011), głowni pylącej kukurydzy (Korbas 2006, 2007), sprawców chorób liści - drobnej plamistości liści kukurydzy oraz żółtej plamistości liści kukurydzy (Tekiela 2005; Korbas 2006), choroby szalonych wiech, a także zgnilizny korzeni i zgorzeli podstawy łodygi (Korbas 2006).

Część wykonywanych w IOR - PIB badań dotyczyła oceny podatności wybranych odmian kukurydzy na najważniejsze choroby, a w szczególności na fuzariozę kolb (Tekiela i wsp. 2010), w tym oceny kukurydzy transgenicznej linii MON 810 na porażenie przez grzyby rodzaju Fusarium i zawartość mikotoksyn (Tekiela i Gabarkiewicz 2007). Z uwagi na duże znaczenie gospodarcze mikotoksyn były one poddawane identyfikacji łącznie z oceną stopnia porażenia kolb przez fuzariozę kolb (Tekiela 2008, 2009).

W doświadczeniach oceniano także efekty pośredniego wpływu zwalczania najważniejszych szkodników kukurydzy na zdrowotność roślin, w tym zawartość metabolitów wtórnych produkowanych przez niektóre patogeny (Tekiela i wsp. 2005).

Obok sprawców chorób pochodzenia grzybowego w pracach badawczych skupiano się również na wirusach, które dotychczas były mało poznaną grupą agrofagów kukurydzy. Roślina ta okazała się gatunkiem często porażanym przez wirusy charakterystyczne dla innych zbóż, jak: wirusy żółtej karłowatości jęczmienia (BYDVMAV i BYDV-PAV), wirusa mozaiki trzciny cukrowej (SCMV) oraz wirusa smugowatej mozaiki pszenicy (WSMV). Stwierdzono także, po raz pierwszy w Polsce, obecność wirusa karłowej mozaiki kukurydzy (MDMV) (Trzmiel i Jeżewska 2006; Trzmiel 2008, 2011).

Prowadzone badania dotyczyły także bakterii występujących na plantacjach kukurydzy. Wykazano w zebranym materiale biologicznym obecność bakterii patogenicznych dla kukurydzy należących do rodzajów: Erwinia, Pantoea, Xanthomonas, Xylophilus, Acidovorax, Enterobacter, Pseudomonas i Bacillus (Krawczyk i wsp. 2011). Sprawdzono także, czy pospolite na plantacjach kukurydzy gatunki chwastów mogą być potencjalnym siedliskiem bakterii przenoszących się później na roślinę uprawną. $Z$ wykonanych doświadczeń wynika, że taką zdolność mogą posiadać chwastnica jednostronna i palusznik krwawy (Krawczyk i wsp. 2010).

Choroby kukurydzy w połączeniu z innymi agrofagami są także obiektem badań prowadzonych $\mathrm{w}$ innych ośrodkach naukowych, a które dotyczą zarówno nasilenia ich występowania, szkodliwości, wpływu nawożenia, gęstości siewu, wczesności, stosowania osadów ściekowych, wysiewu pokolenia F2, opóźniania terminu zbioru, oddziaływania warunków pogodowych, itd. na niektóre gatunki szkodliwe (Sulewska i wsp. 2006, 2007, 2010, 2011; Ptaszyńska i Sulewska 2007; Szymańska i wsp. 2009, 2012).

\section{Podsumowanie / Summation}

Konieczność obligatoryjnego stosowania integrowanej ochrony kukurydzy od 2014 roku nie wprowadza rewolucyjnych zmian $\mathrm{w}$ zabezpieczeniu tej rośliny przed agrofagami, niemniej pozwala zracjonalizować niektóre działania ograniczające zagrożenie ze strony agrofagów. Każdy $\mathrm{z}$ obecnie stosowanych sposobów ograniczania liczebności i szkodliwości organizmów szkodliwych obejmujący użycie metod agrotechnicznych, hodowlanych, biologicznych i chemicznych nadal będzie miał zastosowanie. Z uwagi na toczące się dyskusje nie znana jest jednak przyszłość uprawy kukurydzy GMO w Polsce, w tym linii MON 810, która została autoryzowana do wysiewu w Unii Europejskiej. Zgodnie z rozporządzeniem Rady Ministrów z dnia 2 stycznia 2013 roku, począwszy od 28 stycznia 2013 roku na obszarze Polski zakazany jest wysiew 235 odmian kukurydzy linii MON 810, jakie znajdują się w unijnym katalogu odmian. Podobny zakaz wprowadzono na obszarze Francji, Węgier i Austrii. Główną przesłanką wprowadzenia zakazu stosowania materiału siewnego odmian genetycznie zmodyfikowanej kukurydzy w Polsce zdaniem Rady Ministrów jest zagrożenie zanieczyszczeniem zmodyfikowanym pyłkiem miodów produkowanych w kraju, co może mieć negatywny wpływ na gospodarkę pasieczną.

Kompleksowe rozwiązanie kwestii uprawy kukurydzy GMO (genetically modified organism) w Polsce jest kluczowe zwłaszcza, że metoda biotechnologiczna wymieniana jest jako jedna $\mathrm{z}$ metod integrowanego zwalczania niektórych gatunków szkodliwych między innymi w USA.

Zwiększenie udziału metod niechemicznych w zabiegach integrowanej ochrony kukurydzy pozwala bardziej zrównoważyć wpływ człowieka na agrocenozy. Celem bowiem tej formy ochrony roślin nie jest bezwzględna walka $\mathrm{z}$ organizmami szkodliwymi, ale takie sterowanie liczebnością, które do minimum ograniczy ich wpływ na wysokość i jakość plonu.

$\mathrm{O}$ powodzeniu integrowanej ochrony kukurydzy w dużej mierze decydować będzie podejście samych plantatorów. Będą oni zobowiązani do prowadzenia szczegółowych i systematycznie wykonywanych obserwacji plantacji pod kątem występowania poszczególnych agrofagów, obserwowania cyklu rozwojowego najważniejszych gatunków, poszerzania wiedzy z zakresu ich biologii, szkodliwości i metod zwalczania. Pozwoli to podejmować rolnikom racjonalne decyzje, co do konieczności i terminu zastosowania metod chemicznych.

Pomocą dla plantatorów kukurydzy we wdrażaniu zasad integrowanej ochrony roślin są opracowania wydawane między innymi nakładem IOR - PIB, w których zamieszcza się podstawowe informacje na temat tej formy ochrony upraw przed agrofagami, a które poparte są badaniami prowadzonymi w IOR - PIB oraz innych ośrodkach naukowych. $\mathrm{Z}$ uwagi jednak na ciąły postęp prac 
badawczych i zmieniające się uwarunkowania prawne, organizacyjno-techniczne, a także modyfikacje w rejestrze środków ochrony roślin dopuszczonych do stosowania w Polsce oraz mieszańców kukurydzy dopuszczonych do uprawy w Polsce, konieczne staje się systematyczne aktualizowanie metodyki integrowanej ochrony tej rośliny przed agrofagami, tak aby przekazywała najnowszą wiedzę.

\section{Literatura / References}

Bereś P. 2006. Efekty chemicznego zwalczania omacnicy prosowianki (Ostrinia nubilalis Hbn.) w południowo-wschodniej Polsce w latach 2003-2005. Prog. Plant Prot./Post. Ochr. Roślin 46 (2): 464-467.

Bereś P.K. 2007. Szkodliwość omacnicy prosowianki (Ostrinia nubilalis Hbn.) dla kukurydzy uprawianej w zmianowaniu i monokulturze. Prog. Plant Prot./Post. Ochr. Roślin 47 (1): 184-187.

Bereś P.K. 2008. Efekty biologicznego zwalczania omacnicy prosowianki (Ostrinia nubilalis Hbn.) w południowo-wschodniej Polsce. Prog. Plant Prot./Post. Ochr. Roślin 48 (4): 1281-1284.

Bereś P.K. 2010a. Szkodliwość omacnicy prosowianki (Ostrinia nubilalis Hbn.) dla wybranych odmian kukurydzy o różnej wczesności. Hodowla Roślin i Nasiennictwo 1: 18-23.

Bereś P.K. 2010b. Harmfulness of Ostrinia nublialis Hbn. on some non-Bt versus genetically modified Bt maize (Zea mays L.) cultivars in Poland in 2006-2007. J. Plant Prot. Res. 50 (1): 110-116.

Bereś P.K. 2010c. Efekty chemicznego zwalczania przylżeńców (Thysanoptera) na kukurydzy w okolicach Przeworska w latach 2008-2009. Prog. Plant Prot./Post. Ochr. Roślin 50 (1): 93-97.

Bereś P.K. 2010d. Harmfulness and effects of chemical control of Ostrinia nubilalis Hbn on sweet corn (Zea mays var. saccharata) in Rzeszów region in 2006-2009. Acta Sci. Pol., Agricultura 9 (4): 5-15.

Bereś P.K. 2011a. Mniej znane gatunki z gromady owadów (Insecta) zasiedlające rośliny kukurydzy (Zea mays L.) w południowowschodniej Polsce w latach 2005-2010. Prog. Plant Prot./Post. Ochr. Roślin 51 (1): 21-27.

Bereś P.K. 2011b. Występowanie oraz szkodliwość rolnic (Agrotinae) dla kukurydzy (Zea mays L.) w południowo-wschodniej Polsce w latach 2004-2010. Prog. Plant Prot./Post. Ochr. Roślin 51 (2): 593-598.

Bereś P.K. 2011c. The occurrence of aphids (Aphididae) on maize (Zea mays L.) in Krzeczowice near Przeworsk (south-eastern Poland) in 2005-2008. 2009. Acta Sci. Pol., Agricultura 10 (1): 3-12.

Bereś P.K. 2011d. Usefulness of selected seed dressing for integrated maize (Zea mays L.) protection against frit fly (Oscinella frit L.). Acta Sci. Pol., Agricultura 10 (4): 15-23.

Bereś P.K. 2012a. Flight dynamics of Ostrinia nubilalis Hbn. (Lep., Crambidae) based on the light and pheromone trap catches in Nienadówka (south-eastern Poland) in 2006-2008. J. Plant Prot. Res. 52 (1): 130-138.

Bereś P.K. 2012b. Damage caused by Ostrinia nubilalis Hbn. to fodder maize (Zea mays L.), sweet maize (Zea mays var. saccharata [Sturtev.] L.H. Bailey) and sweet sorghum (Sorghum bicolor [L.] Moench) near Rzeszów (south-eastern Poland) in 2008-2010. Acta Sci. Pol., Agricultura 11 (3): 3-16.

Bereś P.K., Drzewiecki S. 2011. Przydatność wybranych insektycydów do zwalczania chrząszczy Diabrotica virgifera Le Conte w kukurydzy (Zea mays L.). Prog. Plant Prot./Post. Ochr. Roślin 51 (1): 167-176.

Bereś P., Gaj R., Grzebisz W., Kaniuczak Z., Mrówczyński M., Paradowski A., Pruszyński G., Pruszyński S., Siódmiak J., Sulewska H., Tekiela A., Wachowiak H. 2007b. Integrowana Produkcja Kukurydzy (Z. Kaniuczak, S. Pruszyński, red.). Inst. Ochr. Roślin, Poznań, 78 ss.

Bereś P.K., Górski D. 2012. Effect of earliness of maize cultivars (Zea mays L.) on damage caused by Ostrinia nubilalis Hbn. (Lep., Crambidae). Acta Sci. Pol., Agricultura 11 (2): 5-17.

Bereś P.K., Kaniuczak Z. 2010. Opracowanie programów zwalczania stonki kukurydzianej (Diabrotica virgifera LeConte) w Rzeczpospolitej Polskiej. s. 41-59. W: „Ochrona Terytorium Kraju przed Przedostawaniem i Rozprzestrzenianiem się Organizmów Kwarantannowych i Innych Stanowiących Szczególne Zagrożenia”. Inst. Ochr. Roślin - PIB, Poznań, 144 ss.

Bereś P.K., Kaniuczak Z., Sionek R. 2009. Analiza obserwacji nalotu chrząszczy Diabrotica virgifera LeConte na plantacje kukurydzy na podstawie odczytów z pułapek feromonowych i pokarmowych na Podkarpaciu w latach 2006-2008. Prog. Plant Prot./Post. Ochr. Roślin 49 (1): 86-90.

Bereś P.K., Kaniuczak Z., Tekiela A., Mrówczyński M., Pruszyński G., Paradowski A. 2007a. Ochrona kukurydzy przed agrofagami w integrowanej produkcji. Prog. Plant Prot./Post. Ochr. Roślin 47 (4): 275-284.

Bereś P., Lisowicz F. 2005. Przydatność kruszynka (Trichogramma spp.) w ochronie kukurydzy przed omacnicą prosowianką (Ostrinia nubilalis Hbn.) w gospodarstwach ekologicznych. Prog. Plant Prot./Post. Ochr. Roślin 45 (1): 47-51.

Bereś P.K., Pruszyński G. 2008. Ochrona kukurydzy przed szkodnikami w produkcji integrowanej. Acta Sci. Pol., Agricultura 7 (4): $19-32$.

Bereś P.K., Sionek R. 2010. The occurrence and sex ratio of Diabrotica virgifera Le Conte beetles on sweet maize (Zea mays var. saccharata) in south-eastern Poland near Rzeszów in 2007-2009. Veg. Crops Res. Bull. 73: 87-97.

Boller E., Avilla J., Joerg E., Malavolta C., Wijnands F., Esbjerg P. 2004. Integrated Production. Principles and Technical Guidelines. IOBC/WPRS Bull. 27 (2): 1-49.

Boroń M., Mrówczyński M. 2005. Nowe szkodniki w uprawie kukurydzy. Prog. Plant Prot./Post. Ochr. Roślin 45 (1): 68-71.

Drzewiecki S., Pietryga J. 2007. Zwalczanie ważniejszych szkodników w kukurydzy pastewnej insektycydem Proteus 110 OD. Prog. Plant Prot./Post. Ochr. Roślin 47 (1): 209-217.

Drzewiecki S., Pietryga J. 2008. Przydatność nowej zaprawy insektycydowej w zwalczaniu wybranych szkodników kukurydzy. Prog. Plant Prot./Post. Ochr. Roślin 48 (3): 822-825.

Drzewiecki S., Pietryga J. 2009. Obserwacje nad występowaniem zachodniej kukurydzianej stonki korzeniowej (Diabrotica virgifera LeConte) w południowo-zachodnim rejonie Polski. Prog. Plant Prot./Post. Ochr. Roślin 49 (4): 1681-1685.

Haliniarz M., Bojarczyk M. 2007. Szkodliwość omacnicy prosowianki (Ostrinia nubilalis Hbn.) dla transgenicznych i wyjściowych odmian kukurydzy. Prog. Plant Prot./Post. Ochr. Roślin 47 (4): 145-148. 
Kania C. 1962a. Szkodliwa entomofauna kukurydzy obserwowana w okolicach Wrocławia w latach 1956-1959 (cz. I). Pol. Pismo Entomol., Seria B, 1-2 (25-26): 53-69.

Kania C. 1962b. Szkodliwa entomofauna kukurydzy obserwowana w okolicach Wrocławia w latach 1956-1959 (cz. II). Pol. Pismo Entomol., Seria B, 3-4 (27-28): 183-216.

Kierzek K., Paradowski A., Krawczyk R. 2011. Effectiveness of weed control in maize (Zea mays L.) depending on the date and method of herbicide application. Acta Sci. Pol., Agricultura 10 (2): 57-73.

Korbas M. 2006. Głownie kukurydzy i inne choroby - szkodliwość i możliwości zwalczania. Prog. Plant Prot./Post. Ochr. Roślin 46 (1): 354-357.

Korbas M. 2007. Głownia pyląca kukurydzy (Sphacelotheca reiliana) - nowe zagrożenie w Polsce. Prog. Plant Prot./Post. Ochr. Roślin 47 (2): 136-140.

Korbas M. 2008. Sprawcy chorób a zmiany klimatyczne. Prog. Plant Prot./Post. Ochr. Roślin 48 (3): 771-776.

Korbas M., Horoszkiewicz-Janka J. 2007. Znaczenie i możliwości ograniczenia szkodliwych metabolitów pochodzenia grzybowego. Prog. Plant Prot./Post. Ochr. Roślin 47 (2): 141-148.

Korbas M., Horoszkiewicz-Janka J., Jajor E. 2008. Uproszczone systemy uprawy a występowanie sprawców chorób. Prog. Plant Prot./Post. Ochr. Roślin 48 (4): 1431-1438.

Krawczyk K., Kamasa J., Zwolińska A., Maćkowiak-Sochacka A. 2010. Pospolite chwasty polne jako potencjalne siedlisko bakterii patogenicznych dla kukurydzy. Prog. Plant Prot./Post. Ochr. Roślin 50 (1): 221-225.

Krawczyk K., Kamasa J., Zwolińska A., Maćkowiak-Sochacka A. 2011. Występowanie, charakterystyka i diagnostyka chorób bakteryjnych kukurydzy w Polsce. Prog. Plant Prot./Post. Ochr. Roślin 51 (2): 656-661.

Kucharczyk H., Bereś P.K., Dąbrowski Z.T. 2011. The species composition and seasonal dynamics of thrips (Thysanoptera) populations on maize (Zea mays L.) in southeastern Poland. J. Plant Prot. Res. 51 (3): 210-216.

Kuźniar T., Ropek D., Krysa A. 2012. Wykorzystanie grzyba owadobójczego Isaria fumosorosea do ograniczania szkodliwości omacnicy prosowianki (Ostrinia nubilalis Hbn.) w uprawie kukurydzy cukrowej. Prog. Plant Prot./Post. Ochr. Roślin 52 (2): 354-359.

Lisowicz F. 1996. Teoretyczne i praktyczne podstawy zastosowania metod integrowanych w ochronie kukurydzy przed szkodnikami. Prace Nauk. Inst. Ochr. Roślin 36 (1/2): 5-46.

Lisowicz F., Kot J. 1999. Efekty introdukcji kruszynka (Trichogramma spp.) w zwalczaniu omacnicy prosowianki (Ostrinia nubilalis Hbn.) na kukurydzy. Prog. Plant Prot./Post. Ochr. Roślin 39 (2): 493-495.

Lisowicz F., Tekiela A. 2004. Szkodniki i choroby kukurydzy oraz ich zwalczanie. s. 52-64. W: „Technologia Produkcji Kukurydzy” (A. Dubas, red.). Wieś Jutra, Warszawa, 133 ss.

Matyjaszczyk E., Tratwal A., Walczak F. 2010. Wybrane Zagadnienia Ochrony Roślin w Rolnictwie Ekologicznym i Integrowanej Ochronie Roślin. Inst. Ochr. Roślin, Poznań, 103 ss.

Metodyka 2009. Metodyka Integrowanej Produkcji Kukurydzy (Z. Kaniuczak, S. Pruszyński, red.). Państwowa Inspekcja Ochrony Roślin i Nasiennictwa, Warszawa, 47 ss.

Michalski T. 2009. Nie rezygnować z kukurydzy. s. 3-8. W: „Kukurydza Nowe Perspektywy”. Poradnik dla Producentów. Wyd. V. Agro Serwis, Warszawa, 84 ss.

Michalski T. 2012. Kukurydza poszerza kręgi. s. 10-12. W: „Kukurydza w Mistrzowskiej Uprawie. Poradnik Eksperta”. Top Agrar Polska, Poznań, 156 ss.

Michalski T. 2013. Rosnące znaczenie kukurydzy. s. 3-7. W: „Kukurydza Roślina Przyszłości Spełnia Oczekiwania”. Poradnik dla Producentów. Wyd. VII. Agro Serwis, Warszawa, 96 ss.

Mrówczyński M., Pruszyński G., Wachowiak H., Bereś P. 2007. Nowe zagrożenia upraw rolniczych przez szkodniki ze szczególnym uwzgleddnieniem kukurydzy. Prog. Plant Prot./Post. Ochr. Roślin 47 (1): 323-330.

Olszak R.W., Pruszyński S., Lipa J.J., Dąbrowski Z.T. 2000. Rozwój koncepcji i strategii wykorzystania metod oraz środków ochrony roślin. Prog. Plant Prot./Post. Ochr. Roślin 40 (1): 40-50.

Paradowski A. 2008. Alternatywa dla atrazyny w kukurydzy. Prog. Plant Prot./Post. Ochr. Roślin 48 (2): 640-645.

Paradowski A., Kierzek R. 2009. Ekonomiczne aspekty chemicznego odchwaszczania kukurydzy po wycofaniu atrazyny. Prog. Plant Prot./Post. Ochr. Roślin 49 (4): 1630-1636.

PIORiN 2011. Zasięg występowania zachodniej kukurydzianej stonki korzeniowej (Diabrotica virgifera) w 2011 roku. Państwowa Inspekcja Ochrony Roślin i Nasiennictwa, Warszawa. Dostępny w internecie: http://piorin.gov.pl/index.php?pid=1610, dostęp: 12.06.2012.

Pruszyński S., Bartkowski J., Pruszyński G. 2012. Integrowana Ochrona Roślin w Zarysie. Centrum Doradztwa Rolniczego w Brwinowie, Oddział w Poznaniu, Poznań, 56 ss.

Ptaszyńska G., Sulewska H. 2007. Wpływ warunków pogodowych na porażenie kukurydzy grzybem Ustilago zeae Unger. Prog. Plant Prot./Post. Ochr. Roślin 47 (2): 280-283.

Sahajdak A., Bereś P.K., Konefał T. 2006. Diabrotica virgifera Le Conte - a new threat to maize crops in Poland and measures taken against the pest. J. Plant Prot. Res. 46 (2): 157-161.

Skorupska A. 2005. Szkodliwość gryzoni (Rodentia) w uprawach kukurydzy nasiennej. Prog. Plant Prot./Post. Ochr. Roślin 45 (2): $1075-1077$.

Skorupska A. 2011. Reakcja przędziorka chmielowca (Tetranychus urticae Koch) na wybrane odmiany kukurydzy. Prog. Plant Prot./Post. Ochr. Roślin 51 (1): 204-207.

Sobiech Ł., Skrzypczak W., Sulewska H., Michalski T. 2011. Występowanie omacnicy prosowianki (Ostrinia nubilalis Hbn.) i głowni guzowatej (Ustilago zeae Unger.) w uprawie odmian kukurydzy konwencjonalnej i z modyfikacją Bt. Prog. Plant Prot./Post. Ochr. Roślin 51 (3): 1296-1300.

Sulewska H. 2011. Nowy sezon wegetacyjny już za pasem. s. 29-32. W: „Kukurydza Nowe Perspektywy”. Poradnik dla Producentów. Wyd. VI. Agro Serwis, Warszawa, 88 ss.

Sulewska H., Koziara W., Panasiewicz K., Jazic P. 2007. Porażenie roślin kukurydzy grzybem Ustilago zeae Unger. w zależności od zastosowanych nawozów naturalnych. Prog. Plant Prot./Post. Ochr. Roślin 47 (2): 348-351. 
Sulewska H., Koziara W., Ptaszyńska G. 2006. Porażenie roślin kukurydzy przez Fusarium spp. w warunkach opóźniania zbioru. Prog. Plant Prot./Post. Ochr. Roślin 46 (2): 712-714.

Sulewska H., Koziara W., Szymańska G., Panasiewicz K. 2011. Podatność roślin kukurydzy na wybrane agrofagi w zależności od gęstości siewu i wczesności odmian. Prog. Plant Prot./Post. Ochr. Roślin 51 (1): 482-486.

Sulewska H., Ptaszyńska G. 2007. Podatność odmian kukurydzy na ploniarkę zbożówkę (Oscinella frit L.) i omacnicę prosowiankę (Ostrinia nubilalis Hbn.). Prog. Plant Prot./Post. Ochr. Roślin 47 (4): 220-223.

Sulewska H., Szymańska G., Panasiewicz K. 2009. Ocena skuteczności wybranych zapraw insektycydowych stosowanych w kukurydzy. Prog. Plant Prot./Post. Ochr. Roślin 49 (1): 150-153.

Sulewska H., Szymańska G., Panasiewicz K. 2010. Wpływ stosowania osadów ściekowych na zdrowotność kukurydzy w uprawie na ziarno i kiszonkę. Prog. Plant Prot./Post. Ochr. Roślin 50 (2): 748-751.

Szymańska G., Sulewska H., Grochot G. 2011. Zróżnicowanie podatności odmian kukurydzy na choroby i szkodniki. Prog. Plant Prot./Post. Ochr. Roślin 51 (1): 436-440.

Szymańska G., Sulewska H., Panasiewicz K. 2009. Segregacja transgresywna pokolenia F2 kukurydzy w podatności na Fusarium spp. Prog. Plant Prot./Post. Ochr. Roślin 49 (1): 287-291.

Szymańska G., Sulewska H., Panasiewicz K., Koziara W. 2012. Wpływ stosowania nawozu PRP SOL w kukurydzy na występowanie wybranych chorób i szkodników. Prog. Plant Prot./Post. Ochr. Roślin 52 (2): 314-317.

Tekiela A. 2005. Występowanie i szkodliwość drobnej plamistości liści kukurydzy [Aureobasidium zeae (Narita et Hiratsuka) J.N. Dingley] i żółtej plamistości liści kukurydzy (Trichometasphaeria tarcica Luttr.) na kukurydzy w południowo-wschodniej Polsce. Prog. Plant Prot./Post. Ochr. Roślin 45 (1): 484-486.

Tekiela A. 2008. Fuzarioza kolb kukurydzy i skażenie ziarna przez mikotoksyny w Wielkopolsce i na Podkarpaciu. Prog. Plant Prot./Post. Ochr. Roślin 48 (3): 1121-1125.

Tekiela A. 2009. Występowanie fuzariozy kolb kukurydzy w latach 2005-2007 a skażenie ziarna przez mikotoksyny w warunkach Polski. Prog. Plant Prot./Post. Ochr. Roślin 49 (4): 2081-2086.

Tekiela A. 2011. Występowanie głowni guzowatej kukurydzy (Ustilago zeae Beckm.) w południowo-wschodniej Polsce. Prog. Plant Prot./Post. Ochr. Roślin 51 (4): 1655-1658.

Tekiela A., Bereś P., Grajewski J., Miklaszewska B. 2005. Wpływ zwalczania chorób i szkodników kukurydzy na zasiedlenie ziarna przez grzyby i zawartość mikotoksyn. Prog. Plant Prot./Post. Ochr. Roślin 45 (2): 1149-1152.

Tekiela A., Gabarkiewicz R. 2007. Fuzarioza kolb kukurydzy a zagrożenie skażenia ziarna przez mikotoksyny w uprawie mieszańców kukurydzy modyfikowanych genetycznie i ich form wyjściowych w warunkach polskich. Prog. Plant Prot./Post. Ochr. Roślin 47 (4): $227-232$.

Tekiela A., Kozioł M., Mazur A., Wojnarowicz T. 2010. Podatność mieszańców kukurydzy na występowanie fuzariozy kolb kukurydzy. Prog. Plant Prot./Post. Ochr. Roślin 50 (4): 1827-1831.

Trzmiel K. 2008. Diagnostyka wirusa żółtej mozaiki kukurydzy (Maize dwarf mosaic virus, MDMV). Prog. Plant Prot./Post. Ochr. Roślin 48 (3): 1126-1129.

Trzmiel K. 2011. Potencjalna szkodliwość wirusa karłowej mozaiki kukurydzy (Maize dwarf mosaic virus, MDMV) i wirusa mozaiki trzciny cukrowej (Sugarcane mosaic virus, SCMV) dla kukurydzy. Prog. Plant Prot./Post. Ochr. Roślin 51 (1): 307-310.

Trzmiel K., Jeżewska M. 2006. Wstępne wyniki badań nad wirusami występującymi na kukurydzy w Polsce. Prog. Plant Prot./Post. Ochr. Roślin 46 (1): 439-445.

Twardowski J.P., Hurej M., Kordas L. 2008. Impact of transgenic Bt corn on European corn borer (Ostrinia nubilalis Hbn.) in Lower Silesia, Poland. Preliminary results. IOBC/WPRS Bull. 33: 129-132.

Węgorek P., Giebel J. 2008. Działanie wybranych substancji aktywnych w odstraszaniu dzika (Sus scrofa L.) od żerowania w uprawach kukurydzy. Prog. Plant Prot./Post. Ochr. Roślin 48 (3): 1002-1006. 